21 (1), 2020,95-108
Jurnal Pendidikan MIPA
ende-ISSN: 2550-1313|p-ISSN: 2087-9849
http//jurnal.fkip.unila.ac.id/index.php/jpmipa/

\title{
Assessment of the ICT Integration in Teaching Math and Science in High School: Basis for an ICT Integration Program
}

\author{
Gilbert Santos Arrieta ${ }^{1,2}$ \\ ${ }^{1}$ College of Graduate Studies and Teacher Education Research, Philippine Normal University, Philippines \\ ${ }^{2}$ Department of Junior High School, Don Bosco Technical Institute, Philippines
}

\begin{abstract}
This descriptive study assessed the information and communications technology (ICT) integration in teaching Math and Science, and identified issues affecting technology integration. Nine Math teachers, and eight Science teachers was chosen as participant in this study. A survey instrument with Likert-five point scale was developed to explore participants' perceptions towards ICT integration in teaching math and science in high school. The results showed that the status of technology integration in Math and Science is well-implemented. However, teachers needed time to plan and prepare technology-based instructional materials and update their skills in technology and pedagogy. They also needed to be supervised closely through feedback and mentoring. In terms of professional advancement, they needed to be updated and trained on curriculum development, pedagogy, and technology. Equipment and facilities needed to be increased, improved, and maintained, most especially the internet connection. It can be concluded that curriculum and instruction including faculty are greatly dependent on supervision, professional development, and equipment and facilities. The aforementioned three areas are well-implemented which made curriculum and instruction, and faculty extensively implemented.
\end{abstract}

Keywords: ICT integration program, teaching math and science, high school.

Abstrak: Studi deskriptif ini menilai integrasi teknologi informasi dan komunikasi (TIK) dalam pengajaran Matematika dan Sains, dan mengidentifikasi masalah yang mempengaruhi integrasi teknologi. Sembilan guru Matematika, dan delapan guru Sains dipilih sebagai peserta dalam penelitian ini. Instrumen survei dengan skala poin Likert-lima dikembangkan untuk mengeksplorasi persepsi peserta terhadap integrasi TIK dalam pengajaran matematika dan sains di SMA. Hasil penelitian menunjukkan bahwa kondisi integrasi teknologi dalam Matematika dan Sains dilaksanakan dengan baik. Namun, guru membutuhkan waktu untuk merencanakan dan menyiapkan bahan ajar berbasis teknologi dan meningkatkan keterampilan mereka dalam teknologi dan pedagogi. Mereka juga perlu diawasi secara ketat melalui umpan balik dan bimbingan. Dalam hal kemajuan profesional, keterampilan perlu diperbarui dan dilatih tentang pengembangan kurikulum, pedagogi, dan teknologi. Peralatan dan fasilitas perlu ditingkatkan, diperbaiki, dan dipelihara, terutama koneksi internet. Dapat disimpulkan bahwa kurikulum dan pembelajaran termasuk fakultas sangat bergantung pada supervisi, pengembangan profesional, serta peralatan dan fasilitas. Ketiga hal tersebut diimplementasikan dengan baik sehingga kurikulum dan pengajaran, dan fakultas dapat diterapkan secara luas.

Kata kunci: program integrasi TIK, pengajaran matematika dan sains, SMA.

Gilbert Santos Arrieta

Email: arrieta.gs@pnu.edu.ph
DOI: http://dx.doi.org/10.23960/jpmipa/v21i1.pp95-108

Received: 14 March 2020

Accepted: 13 June 2020 


\section{- INTRODUCTION}

Education is a learning process that is exciting, engaging, and challenging. It continues to evolve: curricular programs are revised now and then to meet the challenges brought about by the changes in the environment; researches are conducted to discover new ideas and find ways to make education better; teachers update themselves through seminars and training to continuously become relevant and better facilitators of learning; and school administrators regularly evaluate and plan in order to realize the school's vision-mission.

Teaching and learning were very different in the past. The classroom structure showed teachers completely in control of learning. Since the teacher dominated the classroom activities, class participation was less. Students, as one of the few sources of information, usually just had to listen and write whatever the teacher said and wrote on the board. Also, instructional materials were limited. Students depended only on books and what was written on the blackboard. Through research, new theories on teaching and learning were founded. Schools had to adjust to these new developments and to the inevitable changes of the times. Thus, new teaching methods and strategies were introduced, and more instructional materials were created. Books started to become more affordable, and new teaching aids like flash cards, posters, diagrams, and pictures were developed which made learning more interesting.

As education adapts to changes, learning becomes engaging and challenging. Students begin to become more actively involved in their learning. They participate more in class and ask challenging questions to teachers in order to be enlightened on the lesson. Teachers, in turn, have to constantly update themselves on the current trends in their area of specialization and in education in general so as to teach effectively. They have to adjust their teaching styles, and to engage students in learning even more, they need to prepare instructional materials suited to the lessons. However, the idea that simple exposure to technology would not facilitate 21 st century learning skills. Students and teachers need to interact with technology in order to make it worthwhile in the subject specific activities. It is important to exploit the same technology tools for professional development that teachers use a daily basis. Authentic and current professional development for teachers should use blended learning, collaborative learning, and engage in the challenges of the current context. Many teachers are still struggling to achieve meaningful technology integration within their classrooms while recent emphasis in 21st century skills have pushed technology to the forefront of the classroom and learner experience (Ruggiero \& Mong, 2015).

Today, humanity is entering what seems like the unimaginable atmosphere of the global knowledge or information age. Indeed, today's education is a far cry from what the elders experienced. No doubt, technology is the difference. Born in the digital age, today's learners are called "digital natives". The use of technology plays a pivotal role in their learning. It makes these digital natives wanting to be more engaged and participative in learning. Thus, old methodologies may no longer be effective with them, like the lecture method where students sit for an hour just listening to the teacher. Therefore, new methodologies and instructional materials must be developed, and teachers need to be more creative and innovative to meet the needs of today's learners.

The use of technology in schools was already seen by the United Nations Educational, Scientific and Cultural Organization (UNESCO) more than two decades ago as stipulated in its Framework for Action to Meet Basic Learning Needs. It was pointed out that the quality and delivery of basic education can be enhanced through the 
judicious use of instructional technologies. Where such technologies were not widely used then, it was stated that their introduction would require the selection and/or development of suitable technologies, acquisition of the necessary equipment and operating systems, and the recruitment and training of teachers and other educational personnel to work with them. The definition of a suitable technology would vary by societal characteristics and would change rapidly over time as new technologies (educational radio and television, computers, and various audio-visual instructional devices) would become less expensive and more adaptable to a range of environments. Moreover, UNESCO said that the use of modern technology could also improve the management of basic education, with each country reexamining periodically its present and potential technologies capacity in relation to its basic educational needs and resources (UNESCO, 1990).

The new millennium is characterized as the age of media and technology. Internet use increased, new platforms were created, and more gadgets were introduced in the market in the last ten (10) years. Ipads, tablets, smart phones, e-book readers, laptops, and smart TV became available and accessible. Internet connection was strengthened. New software applications were designed for business and education. Technology may be very overwhelming because of the assumed positive effects on education, but studies show that there is still a lot to be done when it comes to integrating technology in the teaching-learning process. In the early years of technology integration, it was found out that teachers both struggled with incorporating digital tools into instruction and with capitalizing on the affordances of using digital tools. Thus, technology is not a guarantee of effective learning; the technological and pedagogical skills of teachers are important in making it an important tool in learning (Mishra \& Koehler, 2006).

The importance of technology in teaching and learning must be clearly reflected in the vision, plans, and programs of any institution. Before using technology, everyone should believe in its capability and role in education. Discussions about technology must be a key part of the visioning process as it can change the whole nature of the teaching-learning context. The visioning process involving the stakeholders is a way to explore and realize the many opportunities and challenges that can be met through the intelligent use of technology. The advantages and limitations of different technologies for teaching should also be discussed. Arguments and serious deliberations that occur in the visioning process will facilitate in identifying priorities for the use of technology. It will provide a basis in making serious decisions about technology that are nevertheless likely to be supported throughout the organization (Lucas \& Associates, 2000). Technology forms part of school change and reform. It is seen as a way to monitor and standardize procedures already in place. In a student-learning situation, technology can be at the root of change. It can provide students with skills they need for today's workplace (Lucido \& Borabo, 1997).

The use of technology in instruction gave birth to "Educational Technology." Often times, however, it is given a narrow meaning, to mean just hardware when it actually refers to the use of all human inventions and discoveries to satisfy their educational need and desire, i.e., learning. These inventions and discoveries can be devices, tools, equipment, activities, procedures, and processes. Included among these human inventions are the various educational media. Educational technology is more than instructional technology in the same way that education is more than instruction. Technology integration is part of instructional technology which, in turn, is part of educational technology. Also, educational technology is different from technology in 
education. The latter refers to the application of technology in the operation of education institutions while the former refers to the application of technology in the educative process that takes place in such education institutions (Corpuz \& Lucido, 2008).

As technology became an important tool in education, a dramatic shift in the use of instructional materials was seen. Technology-based instructional materials for teaching became very popular. From the ordinary visual aids, today's instructional materials are technology-enhanced and more appealing. However, teachers should be reminded that technology is a tool; it assists in learning. Therefore, technology-based instructional materials must be carefully planned and prepared. Teachers, then, must have the technological and pedagogical skills in preparing these kinds of instructional materials. It is imperative to learn the pedagogy of instructional materials.

There are numerous pedagogical, cultural, and technical challenges that teachers encounter when utilizing technologies. Technology integration is certainly a challenging task, but teachers should always be ready for new developments in education, like technology (Kim \& Freemyer, 2011).Hence, it is critically important that teachers believe in their own abilities to implement these changes within their schools and subject cultures. Even if teachers change their pedagogical beliefs to adopt this new notion of good teaching and gain the knowledge to implement it, they still need confidence to implement it within their specific contexts. Providing opportunities for teachers to both experiment and to succeed is important. Schools can support this initiative by creating aculture that allows teachers to try out new practices, while making technical and pedagogical support readily available (Ertmer \& OttenbreitLeftwich, 2010).

Since the introduction of the Technological Pedagogical Content Knowledge (TPACK), there are sustained efforts to continue monitoring the challenges of teaching with technology. As technology develops, it somehow makes teaching with technology challenging. In their work, the word "technology" applies equally to analog and digital as well as to new and old technologies. As a matter of practical significance, however, most of the technologies under consideration in the current literature are newer and digital and have some inherent properties that make applying them in straightforward ways difficult (Koehler, 2012).

The rapid developments in technology present new challenges to teachers who are struggling to use more technology in their instruction. However, technology integration is not only about using technology. This is another challenge. They interestingly highlighted that at the heart of good teaching with technology are three core components: content, pedagogy, and technology, plus the relationships among and between them. The interactions between and among the three components, playing out differently across diverse contexts, account for the wide variations in the extent and quality of educational technology integration. These three knowledge bases (content, pedagogy, and technology) form the heart of the technology, pedagogy, and content knowledge (TPACK) framework (Koehler, Mishra, \& Cain, 2013). "Faced with these challenges, how can teachers integrate technology into their teaching?" What is needed is an approach that treats teaching as an interaction between what teachers know and how they apply this knowledge in the unique circumstances or contexts within their classrooms. There is no "one best way" to integrate technology into the curriculum. Rather, integration efforts should be creatively designed or structured for particular subject matter ideas in specific classroom contexts. Honoring the idea that teaching with 
technology is a complex, ill-structured task, they proposed that understanding approaches to successful technology integration requires educators to develop new ways of comprehending and accommodating this complexity (Koehler, Mishra, \& Cain, 2013).

Although technology in the classroom is typically deemed to be simply a positive shift in the betterment of students' post-school skills, simply placing technology in the classroom is not enough (Burke, 2000). It does not necessarily follow that access to technology will mean it will be used by classroom teachers. Therefore, to effectively assess technology integration, supervisors need to focus on how the technology is implemented in the classroom, not merely document available materials (Cuban, 2001). Studies on technology integration have been conducted. A summary of reviews of research on computers and education was published in the ACT Policy Report (2004). In the report, it revealed that while not all reviews showed outcomes in favor of computer use, most studies yielded positive conclusions about its effectiveness. He reports general concurrence that when combined with traditional teaching, the use of technology, particularly computers, can increase student learning in the traditional curriculum and basic skills areas.

The integration of computers with traditional instruction produces higher academic results in a variety of subject areas than does traditional teaching alone. Students learn more quickly and with greater comprehension when learning with the use of technology. They like learning with computers, and their attitudes toward learning and school are strongly influenced by computer use. Also, the use of computers appears most promising for low achieving and at-risk students. However, relevant teacher training is an essential element of successful learning programs based on or assisted by technology (Noeth \& Volkov, 2004). These theories and studies strongly recommend that educational institutions must assess their present ICT integration in the teachinglearning process. Once assessed, concerns will be addressed which will pave the way for new developments in technology integration. Technology continues to evolve and will always present new challenges to teachers.

Based on the Technological Pedagogical Content Knowledge (TPACK) by Mishra \& Koehler (2006), Massachusetts Technology Self-Assessment Tool for Teachers (Massachusetts Department of Elementary and Secondary Education), the National ICT Competency Standards (NICS) for Teachers by the Commission on Information and Communications Technology, and Survey Form A for High Schools by the Philippine Accrediting Association of Schools, Colleges and Universities (PAASCU), curriculum and instruction, faculty, supervision, training and development, and equipment and facilities are the areas assessed in this study. Curriculum and instruction refers to the integration of technology in the curriculum and the teaching strategies applied when using technology. The area on faculty refers to the teachers' knowledge and skills on technology, pedagogy, and content. Supervision is about the mentoring of teachers in technology integration in planning and teaching strategies including classroom observation. The area on training and development is about the inservice training and professional development of teachers on technology, pedagogy, and content. Equipment and facilities refers the availability of equipment and facilities including services for technology integration in teaching. 


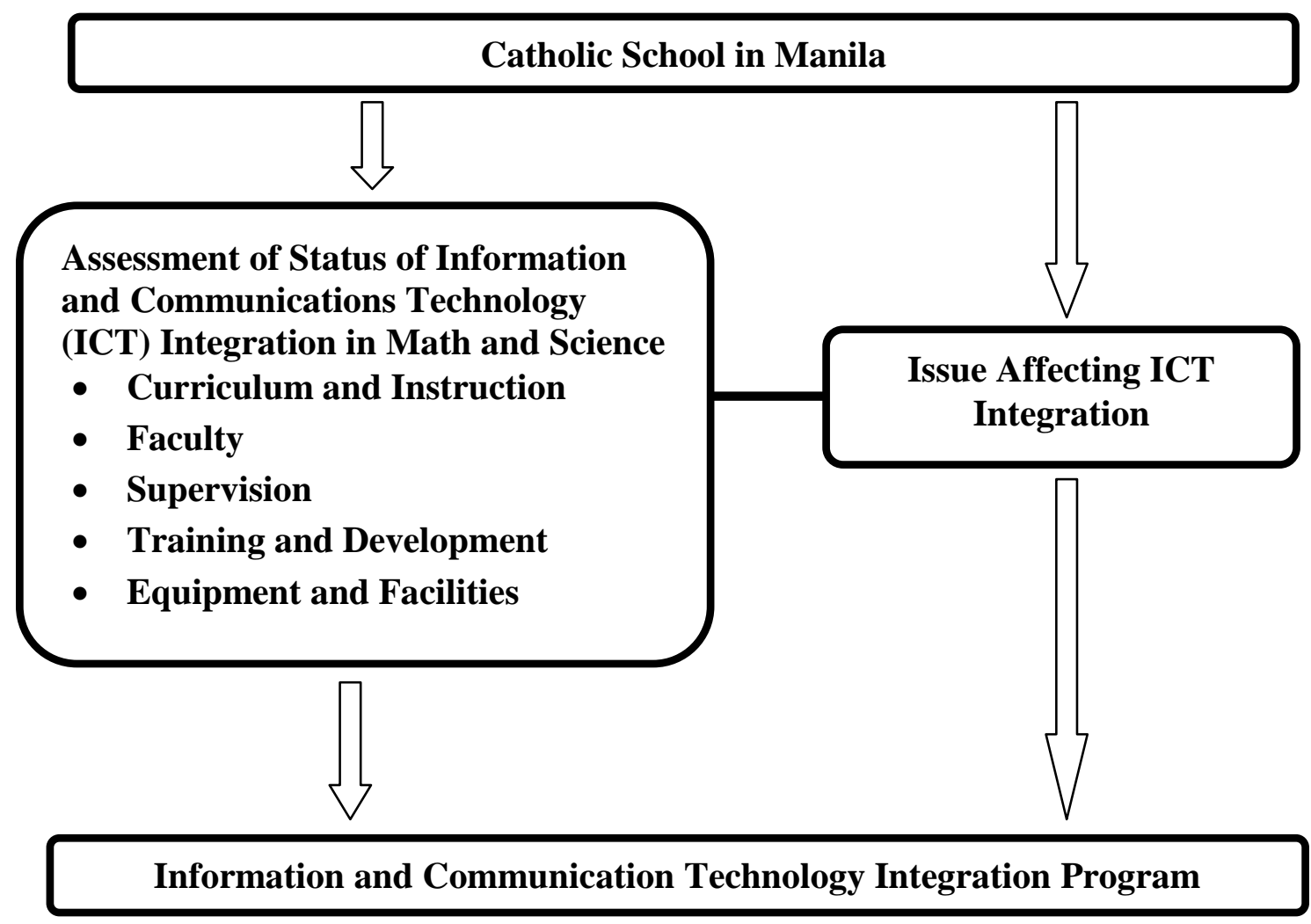

Figure 1. The research paradigm of the study

In the Philippines, both private and public schools have already integrated technology in the teaching-learning process. Budget for technology is appropriated yearly to ensure that technology is available and maintained. Such investment manifests the belief that technology will facilitate learning and improve student performance. The Department of Education (DepEd) Five-Year Information and Communication Technology (ICT) for Education Strategic Plan (DepEd ICT4E Strategic Plan 2009) states that "ICT plays a major role in creating a new and improved model of teaching and learning where education happens anytime, anywhere." The use of ICT will reinvigorate schools to make them into dynamic, collaborative, and innovative learning institutions where students can become more interested, curious, and creative learners. It is the aim of the DepEd that this policy document will provide the direction needed to integrate ICT within the Philippine education system and push the country forward. It aims to completely integrate technology into the curriculum, which includes the development of multimedia instructional materials and ICT-enabled assessment. Also, it intends to intensify competency-based professional development programs and establish the necessary ICT infrastructure and applications. The successful implementation of the ICT4E Strategic Plan will lead to a new era in education.

The DepEd believes that today's learners are growing up in a world characterized by technological change and innovation. It recognizes the need to equip learners with the necessary skills and experiences that will enable them to become productive members of the global community. Also, the DepEd urges the professional teachers to embrace the changes ICT will effect on teaching and learning. For one, teachers' role 
will shift from the traditional provider of knowledge to the facilitator of learning. In order to adapt to such changes, teachers should become habitual users of ICT. They should continue to look for opportunities to upgrade their competencies, share their experiences, and create a culture of collaboration in order to support one another. Schools, in turn, should be responsible for the progressive attainment of these competencies by their teachers as part of their annual performance appraisal. Compliance to this directive of the DepEd and effectiveness of the comprehensive inservice training program will be yearly assessed by the Department.

A Catholic school in Manila began the integration of technology in classroom instruction. In 2000, the library was remodeled and given a new name i.e. Multiple Intelligences Center (MIC). It is the library and instructional media center of the school. In the beginning, instructional materials developer, instructional materials production assistants, and multimedia assistants were hired to assist teachers in the preparation, selection of technology-based instructional materials, and operation of multimedia equipment. Computers were acquired, and teachers were provided computer training. Later, they were provided training on the proper use of technological equipment and pedagogy on the preparation of technology-based instructional materials. Eventually, they became comfortable in the use of technology in teaching. Through the years, more technological equipment were acquired like laptops, multi-media equipment, speakers, TV screens, and computers. Each classroom is now equipped with one LCD projector, screen projector, and TV screen. Each subject area has a laptop and at least two computer units in the faculty room. New software applications were installed, and internet connection was strengthened. Then recently, at the beginning of school year 2015-2016, the MIC was reverted to Library and Learning Resource Center because most of the technology functions were transferred to the Information Technology Center. It was decided that it will function purely as a library with the inclusion only of technology learning resources. Knowing that the teachers can prepare their own technology-based instructional materials, the Institute declared that there is no need for instructional materials development assistants.

The vision-mission of the school is We provide quality education and holistic formation towards social transformation through a curriculum with technological orientation that promotes Gospel values. This clearly shows the importance of technology in education and evangelization. Also, Technological Skills for Life is one of the core values of the school. In 2014, the administration came up with a "Three-Year Institutional Strategic and Educative Pastoral Plan (2014-2017). One of the components of the Plan is curriculum and instruction development. Under this component, there are three action points covering technology integration in teaching, namely (a) to acquire and upgrade equipment that aid instruction and learning, (b) to require teachers to produce instructional materials and supplements, and (c) to make best use of technology in instruction. Also, the curriculum instruction guide and learning plans indicate the use of technology in teaching. This plan can only be achieved through strong leadership practices for building professional capacity including providing teachers with opportunities to learn, creating communities of practice for them, considering their individualized needs, and addressing issues of access and support (Dexter \& Richardson, 2019).

For more than a decade, technology has been integrated in the teaching and learning in the Institute. With all the efforts and investment on the use of technology in learning, it is high time to find out the status of ICT integration in teaching in the high 
school department. Teachers may have been comfortable in using technology, but it does not automatically mean that they are using them appropriately for teaching and learning. They may have the mastery of the content, but they may not be using the appropriate technology and pedagogy. They may be using technology in teaching, but they are not provided training. The action points in the strategic plan of the institute suggest that there are significant actions to be done to improve technology integration in teaching.

With all these points, it is imperative to assess the integration of technology in teaching and learning particularly in Math and Science which are considered challenging subjects. These are also the subjects with more competencies and time allotment in the class schedule. The results of the study will provide inputs for the development of the ICT integration program in teaching and learning particularly in Math and Science.

\section{- METHOD}

The descriptive method of research was used as the principal means in assessing the information and communications technology (ICT) integration in teaching Math and Science. A descriptive study describes and interprets what is. It is concerned with conditions or relationships that exist, opinions that are held, processes that are going on, effects that are evident, or trends that are developing (Best \& Kahn, 1998). The participants in this study were all high school teachers of Math and Science of a Catholic School in Manila. There were nine (9) Math teachers, and eight (8) Science teachers.

The researcher developed a research instrument based on the indicators found in the TPACK survey instrument by Mishra \& Koehler (2010), Massachusetts Technology Self-Assessment Tool for Teachers (Massachusetts Department of Elementary and Secondary Education), National ICT Competency Standards for Teachers by the Commission on Information and Communications Technology, and Survey Form A for High Schools by PAASCU. The Likert-five point rating scale was used. In this study, the mean for every indicator and subject area, including the overall mean, was computed. Likewise, the mean for every area was obtained, including the overall rating. Analysis and interpretation were made. The scale used to define the mean range is presented below. This scale facilitated the interpretation of results.

Table 1. Scale, mean range and its interpretation

\begin{tabular}{ccl}
\hline Scale & Range & \multicolumn{1}{c}{ Descriptive rating } \\
\hline 5 & $4.50-5.00$ & $\begin{array}{l}\text { Excellent. The provisions or conditions are extensively } \\
\text { implemented. }\end{array}$ \\
\hline 4 & $3.50-4.49$ & $\begin{array}{l}\text { Very Good. The provisions or conditions are well } \\
\text { implemented. }\end{array}$ \\
\hline 3 & $2.50-3.49$ & $\begin{array}{l}\text { Good. The provisions or conditions are moderately } \\
\text { implemented. }\end{array}$ \\
\hline 2 & $1.50-2.49$ & $\begin{array}{l}\text { Fair. The provisions or conditions are limited in } \\
\text { implementation. }\end{array}$ \\
\hline 1 & $1.00-1.49$ & $\begin{array}{l}\text { Poor. The provisions or conditions are limited and } \\
\text { poorly implemented. }\end{array}$ \\
\hline
\end{tabular}




\section{- RESULT AND DISCUSSION}

The status of information and communications technology (ICT) integration in the teaching of selected high school subjects in terms of curriculum and instruction, faculty, supervision, training and development, and equipment and facilities are:

\section{Curriculum and Instruction}

Technology integration was evident in the vision-mission, curriculum instruction guide, and learning plan. However, the teachers needed time to collaborate, plan, and prepare technology-based instructional materials. They also have to develop more rubrics in assessing student learning particularly on the use of technology, and use email, blogs, and social media more often in teaching and learning.

\section{Faculty}

The teachers perceived that they have the knowledge and skills on technology, pedagogy, and content integration, including operation of digital devices like computers, laptops, and LCD projector. However, they needed to enhance their knowledge and skills in MS Excel and in configuring computer settings (software and hardware).

\section{Supervision}

The teachers perceived that they are managed and mentored properly in technology integration. However, supervision must be enhanced particularly in providing feedback, guidance, and evaluation of teachers in the use of technology in teaching. They also believed that the orientation on ICT policies is not given regularly to faculty and students.

\section{Training and Development}

The teachers felt that they need to be updated on the latest technological trends in education through orientation and in-service training on curriculum development, and pedagogy on the use of technology. Likewise, they perceived that they have to update themselves through reading of educational books, journals, and websites including research.

\section{Equipment and Facilities}

The resources for technology integration particularly computers, laptops, digital devices in the classrooms, including provision of educational software and materials, were not sufficient. The teachers perceived that technology services need improvement considering the unstable internet connection and lack of regular maintenance services and upgrading of equipment and facilities.

Based on the overall assessment of the respondents, it can be concluded that the status of ICT integration can be described as "Very Good" as indicated by the mean of 4.44 (Table 1). Among the five areas, the respondents rated the Faculty, and Curriculum and Instruction areas as "Excellent" with a mean of 4.75 and 4.61 respectively. This means that it is extensively implemented. They also perceived Supervision, Curriculum and Instruction, Equipment and Facilities, and Training and Development as "Very Good." This means that these areas were well implemented. 
Table 1. Weighted mean for every area

\begin{tabular}{lccc}
\hline \multicolumn{1}{c}{ Area } & Mean & Interpretation & Rank \\
\hline Curriculum and Instruction & 4.61 & Excellent & 2 \\
Faculty & 4.75 & Excellent & 1 \\
Supervision & 4.42 & Very Good & 3 \\
Training and Development & 4.25 & Very Good & 4 \\
Equipment and Facilities & 4.18 & Very Good & 5 \\
\hline \multicolumn{1}{c}{ Overall } & $\mathbf{4 . 4 4}$ & Very Good & \\
\hline
\end{tabular}

The responses of the high school faculty teaching Math and Science on the issues affecting ICT integration were coded or classified by the researcher. Table 2 displays the identified issues. The various issues affecting ICT integration were the need for more time and resources in the planning and preparation of technology-based instructional materials, inadequate in-service training on curriculum development and pedagogy in the use of technology in teaching, and updating of skills in various technologies. Other issues identified are poor internet connection, insufficient equipment like computers and laptops, inadequate technological equipment in the classrooms, and lack of regular upgrading and maintenance of equipment and software. These issues were validated in a study on practices and issues in technology integration. It found out that a majority of the teachers held constructivist pedagogical beliefs about technology integration. This study found that the teachers who held constructivist pedagogical beliefs about technology use had high self-efficacy beliefs about technology use, placed positive value on the use of technology, and had two or more practices of high-level learning in their lessons. Language arts was the subject that gained the most attention for technology integration. Four barriers were students' lack of computer skills, teachers' lack of training in technology, teachers' lack of time to implement technology-integrated lessons, and teachers' lack of technical support (Hsu, 2016).

Table 2. Frequency on the issues affecting technology integration

\begin{tabular}{lc}
\multicolumn{1}{c}{ Issues } & $\boldsymbol{f}$ \\
\hline Insufficient equipment and facilities & 16 \\
Inadequate faculty training and updating on technology and pedagogy & 14 \\
Slow internet connection & 14 \\
Lack of regular maintenance services of equipment and facilities & 11 \\
Upgrading of technological software and equipment & 7 \\
Lack of time preparing technology-based instructional materials & 2 \\
\hline
\end{tabular}

The findings of the study clearly showed that the school strongly supports the use of technology in teaching and learning, and that its teachers have the knowledge and skills in integrating technology in the lessons. Moreover, its vision-mission, curriculum guide, and learning plans reflect the use of technology. In general, technology integration in the Institute is well-implemented, but there are issues and concerns affecting it. In terms of curriculum and instruction, the teachers perceived the need to improve their planning and preparation of technology-based instructional materials. A study revealed that when the teachers were prompted to work with the planning aids during workshop, their initial and primary focus on content and pedagogical considerations was maintained. This may suggest that -as researchers and teacher 
educators- rather than perpetuating the more common focus on the educational affordances of digital tools in educational technology professional development and teacher preparation experiences, we should seek to introduce digital tools and resources primarily vis-à-vis curriculum content and pedagogical methods. In doing so, we would align the design of and emphases for professional learning opportunities more closely with teachers' typical instructional planning approaches (Hofer \& Harris, 2019).

Though teachers perceived that they have the knowledge and skills in using technology for teaching, they believe that they need to update their knowledge and skills and be guided by their immediate head in order to carry out the lessons more effectively. They added that they hunger for new learning in education and technology. They expressed that the seminars and training provided by the administration are insufficient. A research on teacher development on technology integration, it found out that although many teachers are still struggling to achieve meaningful technology integration in their classrooms, recent changes in access, student characteristics, and curricular emphases may provide some much needed impetus in moving teachers' efforts forward. Our hope is that these changes, together with modifications to professional development and district technology plans, will coalesce into a perfect "technology integration" storm that continues to empower more and more teachers to use technology in ways that prepare our students for the future they will inherit (Ertmer, Ottenbreit-Leftwich, Sadik, Sendurur \& Sendurur, 2012). Similarly, technology integration education appears to strongly influence teachers' attitudes toward computers. The direct effect of teacher technology integration education on students is weaker although also present. Training appears to foster meaningful use by teachers in the classroom, which, in turn, fosters student computer enjoyment and later a perception of importance of computers. In addition, however, it also appears that greater positive perception of computer importance among the students in a classroom also fosters higher computer anxiety in their teachers. This implies that teachers need some mechanism at their disposal - ongoing education, for example - that continues to reduce their anxiety more rapidly than the advancing skill level of their students, which tends to put pressure on them, causing teacher anxiety levels to increase. Findings from this study support the contention that funding ongoing technology integration education for teachers is a crucial component for having technology make a difference in the education of our students (Christensen, 2002).

Lack of time to prepare technology-based instructional materials appeared to be an issue. Over the years as equipment and connectivity have significantly improved, time continues to be a concern. In a study on the barriers to technology integration that continue to make it difficult for teachers to use educational technologies in the classroom,results indicate that time was the most stable and persistent barrier to technology integration. Access to technology tools and resources increased, yet teacher beliefs, and training and technical support declined over time. Teachers from smaller school districts reported higher access to technology tools and resources and higher administrative support. Recommendations to improve educational technology integration in K-12 schools are provided (Francom, 2020).

Moreover, though budget for technological equipment and facilities is allocated yearly, the teachers perceived that the equipment and their maintenance services are inadequate. A research revealed the strong desire to see the school become technologically equipped and have developed a long-term technology plan for reaching this goal. Additionally, they consciously invest in technology each year in an attempt to 
move toward those goals. Because of these actions, I believe that the administration and school board would be very interested in the information contained in this thesis and support the program that is based on the research completed. Although it would only be solidified after budgetary considerations, the administration would also consider budgetary investments in the program. Essentially, the purpose of the first phase of this professional development program is to evaluate and create a school culture that supports and encourages ICT integration. It is important to minimize the obstacles that teachers will encounter if the program is to be effective in empowering them to increase ICT integration in their classrooms (Faulder, 2011). In another study, financial cost was viewed as the largest barrier to usage. By better understanding science teachers' use of technology in the field, school administrators and teachers themselves may identify new strategies to implement technology (Kormos, Medina \& Zipper, 2019).

The findings suggest that technology integration will be extensively implemented if the strengths are maintained and the issues addressed. It is proposed, then, that an ICT Integration Program should be developed to ensure that the teachers will utilize technology for teaching and learning effectively, and that the administration will provide direction, supervision, training, equipment, and support services in technology integration. Through the Program, better teacher performance will be achieved as teachers' design and use technology that best suit their students. Students' performance will also improve as they become more interested and participative in class. The Proposed ICT Integration Program (2016-2019) for this Catholic school in Manila, developed based on the inputs derived in this study, is created by the researcher.

\section{- CONCLUSION}

This study assessed the ICT integration in teaching Math and Science particularly in terms of curriculum and instruction, faculty, supervision, training and development, and equipment and facilities. It also identified the issues affecting the ICT integration, and the findings will be used as inputs to develop an ICT integration program for the school.

Based on the findings of the study, it can be concluded that the integration of information and communications technology (ICT) in the teaching of selected high school subjects is well implemented. The administration supports ICT integration in teaching and learning as reflected in the Institute's vision-mission and curricular programs. However, the administrators and academic heads need to closely supervise teachers in technology integration and use of social media in teaching and learning through feedback and mentoring. The orientation on ICT policies and procedures is not regularly provided to students and teachers. Another concern is the training of teachers on curriculum development, pedagogy, and technology, which the administration inadequately provides. In terms of equipment, facilities and technical support, these are provided by the administration, but they are insufficient and need updating.

It can also be concluded that the teachers have the knowledge and skills in using technology for teaching and learning, but they need time to plan and prepare technology-based instructional materials. Also, they want to update their knowledge and skills in various educational technologies including social media and MS Excel as they integrate them in teaching and learning. Teaching and learning will become more creative, interesting, and engaging if technology integration is extensively implemented. Further studies on technology integration may be conducted particularly on the effects of the utilization of technology on teachers and students' performance. 
After considering the above findings and conclusions, there are several recommendations that can be provided. Firstly, teachers should be provided with sufficient time to plan, prepare, collaborate, and create technology-based instructional materials. To be better in integrating technology, they should be given in-service training program on curriculum development and pedagogy on the use of technology in teaching. Secondly, supervision of teachers particularly on technology integration and use of email and social media in teaching and learning safeguarded by ethics must be enhanced through feedback and mentoring. Thirdly, additional laptops, computer units, and technological equipment for classrooms should be acquired including maintenance and updating services on equipment and facilities. Internet connection must be provided and strengthened. Lastly, a study on the effects of technology in teaching and learning particularly on teachers and students' performance may be conducted in schools which have fully integrated technology in the teaching-learning process.

\section{- REFERENCES}

Best, J. W. (1998). Research in Education (8th Edition). Singapore: Allyn and Bacon.

Christensen, R. (2002). Effects of Technology Integration Education on the Attitudes of Teachers and Students. Journal of Research on Technology in Education, 34(4), 411-433.

Commission on Information and Communications Technology. National ICT Competency Standards (NICS) for Teachers. http://www.ncc.gov.ph/nics/files/ NICS-Teachers.pdf

Corpuz, B. B. \& Lucido, P. I. (2008). Educational Technology 1. Quezon City: Lorimar Publishing Company

Department of Education. Five-Year Information and Communication Technology for Education Strategic Plan (DepEd ICT4E Strategic Plan). http://planipolis.iiep. unesco.org/upload/Philippines/Philippines_ICT4E_Strategic_Plan.pdf

Dexter, S., \& Richardson, J. W. (2019). What does technology integration research tell us about the leadership of technology? Journal of Research on Technology in Education, 52(1), 17-36.

Ertmer, P. A., Ottenbreit-Leftwich, A. T., Sadik, O., Sendurur, E., \& Sendurur, P. (2012). Teacher beliefs and technology integration practices: A critical relationship. Computers \& Education, 59(2), 423-435.

Ertmer, P. A., \& Ottenbreit-Leftwich, A. T. (2010). Teacher technology change. Journal of Research on Technology in Education, 42(3), 255-284.

Faulder, T. R. (2011). Technology Integration: A Research-based Professional Development Program. Master of Education Research Theses. 30. Retrieved from http://digitalcommons.cedarville.edu/education_theses/30.

Francom, G. M. (2020). Barriers to technology integration: A time-series survey study, Journal of Research on Technology in Education, 52(1), 1-16,

Harvey, D. M. , \& Caro, R. A. (2017). Herring, M. C., Koehler, M. J., \& Mishra, P. (Eds.) (2016). Handbook of technological pedagogical content knowledge (TPACK) for educators. (2nd edition). New York: Routledge. TechTrends, 61(4), 404-405.

Hofer, M., \& Harris, J. (2019, March). Topics and sequences in experienced teachers' instructional planning: Addressing a $~ 30$-year literature gap. In Society for Information Technology \& Teacher Education International Conference (pp. 
2443-2452). Association for the Advancement of Computing in Education (AACE).

Hsu, P. (2016). Examining current beliefs, practices and barriers about technology integration: A case study, TechTrends, 60, 30-40.

Kim, M. C., \& Freemyer, S. (2011). Technology integration in science classrooms: Framework, principles, and examples. Educational Technology, 25-29.

Koehler, M. (2012). TPACK Explained. [Webpage]. TPACK ORG. Retrieved from: http://www.tpack.org/

Koehler, M. J., \& Mishra, P. (2005). What happens when teachers design educational technology? The development of technological pedagogical content knowledge. Journal of Educational Computing Research, 32(2), 131-152.

Koehler, M. J., Mishra, P., Bouck, E. C., DeSchryver, M., Kereluik, K., Shin, T. S., \& Wolf, L. G. (2011). Deep-play: Developing TPACK for 21st century teachers. International Journal of Learning Technology, 6(2), 146-163.

Kormos, E., Medina, J., \& Zipper, P. (2019, June). Influences on Science Teacher Technology Acquisition and Integration Within International Schools. In EdMedia+ Innovate Learning (pp. 772-777). Association for the Advancement of Computing in Education (AACE).

Lucas, A. F. (2000). Leading Academic Change: Essential Roles for Department Chairs. The Jossey-Bass Higher and Adult Education Series. Jossey-Bass Publishers, 350 Sansome Street, San Francisco, CA 94104.

Lucido, P. (2007). Educational technology 2: Selection, production, and utilization of appropriate technology tools in instruction. Quezon City, Philippines: Lorimar Publishing Inc.

Lucido, P. \& Corpuz, B. (2001). Educational Technology. Quezon City: Katha Publishing Co., Inc.

Mishra, P., \& Koehler, M. J. (2006). Technological pedagogical content knowledge: A framework for teacher knowledge. Teachers College Record, 108(6), 1017-1054.

Noeth, R. J., \& Volkov, B. B. (2004). Evaluating the effectiveness of technology in our schools: ACT policy report, American College Testing ACT Inc, 1-21.

Ruggiero, D., \& J. Mong, C. (2015). The Teacher Technology Integration Experience: Practice and Reflection in the Classroom. Journal of Information Technology Education Research, 14, 161-178.

UNESCO, United Nations Educational Scientific and Cultural Organization. (1990). World Declaration on Education for All. In UNESCO (Ed.): World Declaration on Education for All and Framework for Action to Meet Basic Learning Needs. Adopted by the World Conference on Education for All: Meeting Basic Learning Needs, Jomtien,Thailand, 5-9 March 1990. Paris: UNESCO. 